\title{
Measuring Moral Judgment of Education Profession Ethics Among Pre-Service Teachers of the School of Educational Sciences at the University of Jordan
}

\author{
Nisreen M. Al-Disi ${ }^{1} \&$ Saleh Moh'd Rawadieh ${ }^{1}$ \\ ${ }^{1}$ Department of Curriculum and Teaching, School of Educational Sciences, University of Jordan, Amman, Jordan \\ Correspondence: Nisreen M. Al-Disi, Department of Curriculum and Teaching, School of Educational Sciences, \\ University of Jordan, Amman, Jordan.
}

Received: August 5, 2019

doi:10.5539/ies.v12n12p71
Accepted: September 10, $2019 \quad$ Online Published: November 29, 2019

URL: https://doi.org/10.5539/ies.v12n12p71

\begin{abstract}
This study aimed at identifying moral judgment for education profession ethics among pre-service teachers programs of the School of Educational Sciences at the University of Jordan. Accordingly, the researchers developed a Moral Judgment Scale based on Kohlberg (1984), and on the Adult Moral Judgment Scale localized by Abdul-Fattah (2001). The scale consisted of five dilemmas related to ethics in education profession. Validity and reliability of the scale were confirmed. Study population involved (420) students from (5) programs in the academic year 2018/2019. The results of the study showed that the prevailing moral judgement is the second level (conventional morality) of Kohlberg with (308) students of (89.3\%), and the fourth stage (Upholding/enforcing norms and laws) with (245) students of (71\%) of total students. No students were in the first level, stage 1, stage 2, nor in stage 6 . However, significant differences were observed in the level of moral judgment attributable to the academic achievement variable, while no differences were attributable to the program specialization. Moreover, significant differences were found in the moral judgment stages attributable to the academic achievement and students' program. These findings argue for investment in pre-service teachers' education to increase their moral judgment during education profession.
\end{abstract}

Keywords: Kohlberg, moral judgement, pre-service teachers, ethics in education profession, Jordan

\section{Introduction}

Teachers are the cornerstone of the success of the educational process. They are a good example for students, and enlightening their path inside and outside the school.

Teaching was described as a moral project (Goodlad, Soder, \& Sirotnik, 1990). So, teachers should be able to make proper moral judgments. The moral teacher will recognize and respect the basic value and the dignity of all human beings (Cummings, Dyas, Maddux, \& Kochman, 2001). This emphasizes the need to prepare teachers professionally and focus on their moral development to carry out such roles professionally (Honig \& Lalonde, 2014).

However, many students leave colleges and universities with a vague understanding of what is expected of them by the community, their peers and their profession. The way in which teachers are prepared in terms of the ethical dimensions of their profession is inconsistent with the general orientation of professionalization of the teaching profession and does not correspond to the importance of professional rules of conduct (Maxwell, 2017).

Education literature refers to the need for the moral professional development of pre-service teachers, stressing that the teacher is the role model for learners (Weissbourd, 2003; Berkowitz \& Bier, 2004; Nucci, Drill, Larson, \& Browne, 2005). Many studies indicate that professional ethics is one of the neglected subjects by many teacher education programs around the world. The work on educating teachers' professional ethics has lagged behind the teaching of professional ethics in medical schools, law and business, which led some educational systems to hold specialized courses and workshops in the ethics of the education profession along the lines of other professions (Warnick \& Silverman, 2011; Winston, 2007).

Maxwell (2017) argues that the way future teachers are being initiated into the ethical dimensions of their future profession is largely out of step with the movement to professional teaching. After recalling the role that codes of 
professional conduct play in the professional self-regulation, and arguing that familiarizing students with their local code of ethics should be considered as the bare minimum of an adequate ethics education for professionals.

Little is known about how teacher candidates are being prepared to face the ethical challenges of contemporary teaching. The findings of an international survey involving five Organizations for Economic Co-Operation and Development (OECD) countries - the United States, England, Canada, Australia, and the Netherlands - shed light on teacher educators' perspectives on the contribution of ethics content to the education of future teachers and provided a snapshot of how well existing programs line up with their aspirations. Results showed that $(24 \%)$ of the initial teacher education programs surveyed contain at least one mandatory stand-alone ethics course. Researchers recommended for opportunities expanding ethics education in preservice teaching programs (Maxwell, Tremblay-Laprise, and Filion, Boon, Daly, Hoven, Heilbronn, Lenselink \& Walters, 2016).

The first Arab attempt in the area of teaching ethics profession began in 1968. The conference of the Arab Ministry of Education adopted the Charter of the Arab Teacher, which consists of 19 items, with the definition of the profession. The Arab Organization Education, Culture and Science presented a moral constitution for the profession of education during a seminar held in 1979 in Muscat, and dealt with the concept of the constitution and its importance and objectives, and the responsibilities of the teacher towards his profession and towards society (Al-Hjrieh, 2009, p. 39).

The Jordanian Ministry of Education (2018) announced the code of ethics for teachers as the main pillar in the development of a positive societal image of education in the Kingdom in general. The aim of the Code is to improve teachers' self-esteem, encourage constructive self-criticism, increase their ability to make the best choices regarding their behavior and ethics, and provide teachers with role models for society.

\subsection{Kohlbergs' Moral Development Theory}

The theory of Lawrence Kohlberg (moral judgement or moral reasoning) is one of the richest theories in the research of moral development. Kohlberg was interested in Piaget's ideas and theories, influenced by the ideas of John Dewey and other philosophers and scholars. Kohlberg defines the concept of moral thinking as "an advanced movement towards establishing judgment, choice, and thinking about the concepts of justice" (Kohlberg, 1984: $33)$.

Kohlberg has developed a model for the stages of moral reasoning, in which he has relied on presenting different dilemmas, in which there is a conflict between compliance with social legal norms and power orders on one hand and the human need for the well-being of others on the other (Killen \& Smetana, 2006). Kohlberg (1984) maintained that moral cognition develops through three levels each consist of two stages. The researchers outlined these levels and stages in Figure 1.

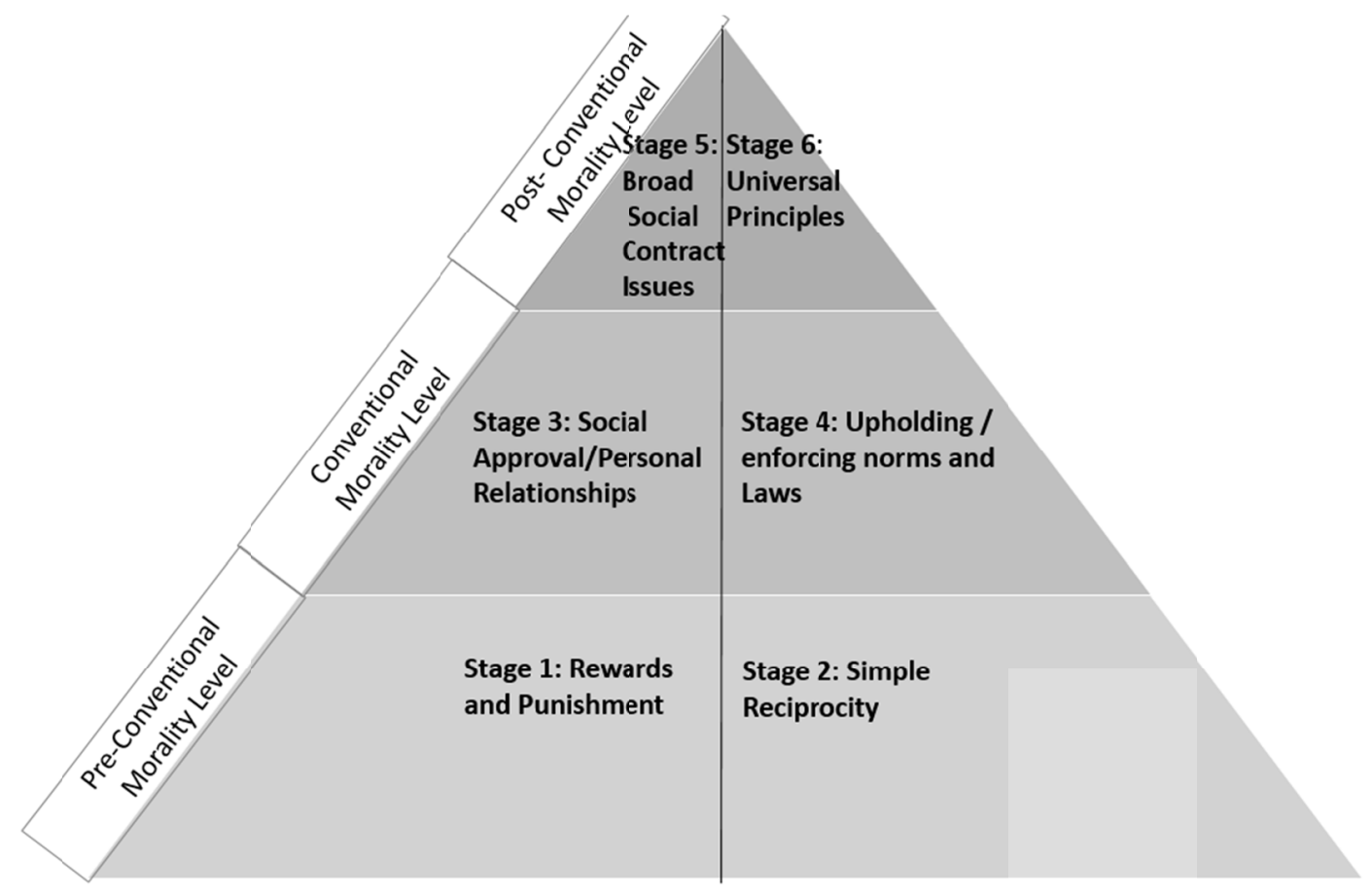

Figure 1. Kohlberg moral development structure 
Kohlberg's research led him to develop six stages of moral development, and he claimed that each new stage was psychologically better than the previous stage. In the pre-conventional level (Stages 1 and 2), moral rules and norms are imposed on people from external authorities. People whose responses fall within the conventional level (Stages 3 and 4) internalize the expectations of authority. While, at the post-conventional level (Stage 5 and Stage 6), moral options are best defined by self-chosen principles (Lapsley, 1996).

According to Colby and Kohlberg (1987), the highest level (post-conventional morality) of Kohlberg is based on the principal of justice, and the ability to care for others "perspective taking" which is an essential component of moral reasoning. Kohlberg has called the post-conventional level, the principled level of moral reasoning. Individuals progress through these stages due to their maturation, developing cognitive ability, and education.

Kohlberg used the first, individual standard and most widely used test measure moral reasoning, the Moral Judgment Interview (MJI) (Colby et al., 1987). Despite the extensive application of this test, negative administration issues were noted (long-time and experience of the interviewer) when applying the test. Consequently, Rest (1979) developed the Test of Specific Issues (DIT) which has become a more popular measure of moral thinking. DIT, contains moral dilemmas (virtual) that is followed by a multi-choice questions based on the classification of Kohlberg ethical stages.

\subsection{Literature Review}

Different studies were performed to measure moral reasoning of individuals locally and internationally. Al-Raqqad and Al-Khawaldeh (2016) conducted a study aimed at identifying the moral reasoning levels and the ability of decision making among students of the University of Jordan. Study sample consisted of (915) students selected from the first semester of the academic year 2014/2015. Researchers used Kolhberg Test translated and localized by Abdul Fattah (2001), and developed the decision-making test. Study results showed that the level of moral thinking and the decision making ability of students at the University of Jordan came to a medium level, in addition to a positive relationship between the level of moral thinking and the ability of students to make the decision.

Migdady (2015) conducted a study aimed to identify the moral reasoning of all the eudemonic well-being of positive social behavior. A random sample of 237 students was selected from the undergraduates in the Faculty of Education at Al-Baha University, Saudi Arabia. Results showed that the level of moral reasoning, eudemonic well-being, and the positive social behavior were moderate.

Maqaldeh and Bani-Mustafa (2014) conducted a study aimed at identifying the level of moral thinking among students of Yarmouk University in Jordan. The study sample consisted of (500) students from Yarmouk University who were selected in the second semester of the year 2012-2013. The results of the study showed that the level of moral thinking came to a moderate degree in the fourth stage, which is strict adherence to laws and regulations of Kohlberg moral thinking theory.

Khatib (1988) conducted a study aimed at determining the distribution of students of the University of Jordan on the stages of moral growth as defined by Kohlberg, and whether this distribution varies depending on the sex of students and different social environments (rural, city). The study population consisted of all undergraduate students studying at the University of Jordan, and the sample of the study was chosen from the university students to represent their faculties and levels of study. Students: (158) males and (176) females distributed at the first, second, third and fourth levels $(98 \%, 86 \%, 98 \%$ and $57 \%$ respectively). To determine the ethical phases of the university students, the Rest test was used to measure moral growth after it was developed for the Jordanian environment and extracted the signs of honesty and consistency. The results of the study indicated that the majority of respondents fall in the fourth stage $(68 \%)$ while the remaining percentages are distributed to the third and fifth phases. None of the respondents were in any of the first, second and sixth stages.

In a comparison study of cultural dimensions and moral reasoning (Wihelm \& Gunawong, 2015) in student and graduate populations in Thailand and the USA, results showed there were both psychological and cultural differences between the two nations that affect moral reasoning. Predominant status quo moral reasoning predominates in Thailand, while a polarity between self-interest moral reasoning and higher level abstract idealistic moral reasoning predominates in the USA.

King and Mayhew (2002) reviewed 172 studies that investigated the moral development of undergraduate college students which provided an organizational framework for analyzing educational contexts in higher education. Effects of age and education on the development of moral reasoning were examined in a series of longitudinal studies. These studies suggest that institutional experiences promote moral development in which students tend to decrease their fondness for conventional level reasoning and increase their preference for the post-conventional moral reasoning. Other longitudinal studies have followed the development of moral thinking by testing students 
twice during their institutional experience, at the beginning of the first year and at the end of the last year. Others tracked the course of moral judgement development of participants from the end of high school up to six years beyond high school.

In this context, studies of moral thinking in western culture have been studied on a large scale. However, it is necessary to ask about the same thing and how the moral judgment of pre-service teachers can better interact to understand the foundations of moral judgment in the School of Educational Sciences at the University of Jordan.

\subsection{Purpose of the Study}

Many burdens in Jordanian educational system were announced, such as the programs at the faculties of education, in-service training programs, teachers' recruiting policy, motivating teachers to perform, etc. These shortcomings are among the main challenges that must be addressed seriously to develop the Jordanian educational system (Sawalmeh, 2014).

Therefore, this study aims at identifying the moral judgment for education profession ethics among pre-service teachers' programs of the School of Educational Sciences at the University of Jordan. According to the literature review performed by the researchers, this is the first research study developing a moral judgement scale for measuring moral judgement for education profession ethics among pre-service teachers of the School of Educational Sciences at the University of Jordan. Hence, this study can be a source of data for administrators and decision making managers at the University of Jordan and Jordan Ministry of Education, as well as to researchers interested in the subject.

\subsection{Research Questions}

This study addresses four specific research questions:

1) What is the level of moral judgment among the students of the School of Educational Sciences at the University of Jordan?

2) What is the moral judgment stage among the students of the School of Educational Sciences at the University of Jordan?

3) Are there statistically significant differences $(\alpha=0.05)$ between the arithmetical averages of moral judgment levels of education profession ethics due to the academic achievement and the program of students at the School of Educational Sciences at the University of Jordan?

4) Are there statistically significant differences $(\alpha=0.05)$ between the arithmetical averages of moral judgment stage of education profession ethics due to the academic achievement and the program of students at the School of Educational Sciences at the University of Jordan?

\section{Methodology}

\subsection{Study Design}

The researchers used the analytical descriptive approach for conducting this study.

\subsection{Study Variables}

\subsubsection{Program}

It is the undergraduate educational program accredited by the School of Educational Sciences at the University of Jordan to grant a bachelor's degree. The accredited programs which are included in this study are: Classroom teacher programs, Counseling and Mental health, Early Childhood Education, Library and Information Science, and Special Education.

\subsubsection{Academic Achievement}

It is the cumulative rate of the student in accordance with the instructions to grant a bachelor's degree in the University of Jordan. For the purpose of this study, students' cumulative grade of $\leq 2.95$ are considered "Low Academic Achievement" students, while cumulative grade of $\geq 2.96$, are considered "High Academic Achievement" students.

\subsection{Study Population}

The study population consisted of undergraduate students in the School of Educational Sciences in their fourth year in the academic year 2018/2019. Total number of students was (420) according to the statistics of the Admission and Registration Department at the University of Jordan. "Female Students" accounted for (92.38\%) of the total study population. Therefore, gender was not considered among the study variables. Distribution of study population according to the study variables is presented in Table 1. 
Table 1. Distribution of the Study Population

\begin{tabular}{lcccccc}
\hline \multirow{2}{*}{ Number of Students } & & \multicolumn{3}{c}{ Academic Achievement } \\
\cline { 5 - 7 } & & & \multicolumn{3}{c}{ Low } & \multicolumn{3}{c}{ High } \\
\hline Program & $\mathrm{f}$ & $\%$ & $\mathrm{f}$ & $\%$ & $\mathrm{f}$ & $\%$ \\
Classroom teacher & 134 & $31.90 \%$ & 58 & $31.48 \%$ & 76 & $34.97 \%$ \\
Counseling and Mental health & 91 & $21.67 \%$ & 41 & $21.60 \%$ & 50 & $22.95 \%$ \\
Early Childhood Education & 43 & $10.24 \%$ & 24 & $12.35 \%$ & 19 & $8.20 \%$ \\
Library and Information Science & 45 & $10.71 \%$ & 26 & $11.11 \%$ & 19 & $7.10 \%$ \\
Special Education & 107 & $25.48 \%$ & 47 & $23.46 \%$ & 60 & $26.78 \%$ \\
Total & 420 & $100 \%$ & 196 & $100 \%$ & 224 & $100 \%$ \\
\hline
\end{tabular}

Table 1 shows that "Classroom Teacher" program has the highest frequency, (134) students with (31.90\%), while the lowest frequency is for "Early Childhood Education" program, (43) students with (10.24\%). It is also presented that "High Academic Achievement" students are prevailing among the study population with (224) students. Distribution of students according to the "academic achievement" variable shows that students of "High Academic Achievement" are having a higher share than the "Low Academic Students" in the "classroom teacher", "Counseling and Mental health", and "Special Education" programs. While the "Low Academic Achievement" students are having a higher share than the "High Academic Achievement" students in the "Early Childhood Education" and the "Library and Information Science" programs.

\subsection{Study Participants}

The researchers chose randomly (345) students contributing to (82\%) from the study population, as the study participants. The researchers considered this number and percentage sufficient for the purpose of this study.

\subsection{Data Collection Tool}

The researchers developed a Moral Judgment Scale to measure education profession ethics based on the moral development theory of Kohlberg (1984) and the Adult Moral Judgment Scale localized and developed by Abdul-Fattah (2001), taking into consideration the following:

- The stages of moral growth are successive and collective stages. Kohlberg believes that morality does not grow once, and that it is subject to a series of stages, and follow these stages regularly. Individuals go through these stages at different speeds without the individual going beyond one stage to the next.

- The moral growth of the individual is within the individual's development ability to think and make judgments. A person's moral judgment can be measured by presenting life scenarios (dilemmas) that contain virtual (not real) ethical stories.

- The focus of measuring moral judgment depends on measuring the individual's ability to think rather than on measuring the individual's response to the moral dilemmas that are presented. The thinking processes of an individual lead to the moral judgment that will be taken.

- Applying the test and correcting it in an objective manner. The respondent selects one response in a selective form (multiple choices). Each response represents a specific stage of the six stages of the Kohlberg theory.

\subsubsection{Moral Judgment Scale Content}

The developed Moral Judgment Scale contained five different dilemmas. The researchers derived the second and the third dilemmas according to Kohlberg (1984), the first and the fourth dilemmas according to Abdul Fattah (2001). Moreover, the researchers developed the fifth dilemma and all the questions (20) that follow the five dilemmas (see Table 2). 
Table 2. Moral judgement scale dilemmas

\begin{tabular}{|c|c|}
\hline Dilemma & Content; number of following questions \\
\hline $\begin{array}{l}\text { First } \\
\text { Dilemma }\end{array}$ & $\begin{array}{l}\text { The story of a fire spreading to a school, where a teacher leaves his work to help his children who may have been hurt by the fire, } \\
\text { even though it is the teachers' duty to abide by location according to instructions in order to protect and save the class students. } \\
\text { The first dilemma is followed by five questions. }\end{array}$ \\
\hline $\begin{array}{l}\text { Second } \\
\text { Dilemma }\end{array}$ & $\begin{array}{l}\text { The story of a student who wishes to participate in a school celebration, and after the teacher promised the student to participate } \\
\text { provided high grades are achieved by the student, the teacher changed his opinion and decided to share his child instead of the } \\
\text { student. The second dilemma is followed by five questions. }\end{array}$ \\
\hline $\begin{array}{l}\text { Third } \\
\text { Dilemma }\end{array}$ & $\begin{array}{l}\text { The story of a teacher whose wife was on her deathbed and he tried to collect money for her treatment, but managed to collect } \\
\text { half of the amount required, so the teacher tried to borrow the remaining amount from the owner (manager) of the school he } \\
\text { works at, but the owner was not convinced and refused. The third dilemma is followed by five questions. }\end{array}$ \\
\hline $\begin{array}{l}\text { Fourth } \\
\text { Dilemma }\end{array}$ & $\begin{array}{l}\text { The story of a teacher who was sentenced for five years in prison but managed to escape. Eight years later, at one of the } \\
\text { celebrations organized by the school where the teacher works at, one of the parents identified the teacher as the fugitive prisoner } \\
\text { whom the police were looking for. The fourth dilemma is followed by three questions. }\end{array}$ \\
\hline $\begin{array}{l}\text { Fifth } \\
\text { Dilemma }\end{array}$ & $\begin{array}{l}\text { The story of a superior student suffering from a family problem that affects student performance and failed to answer in the final } \\
\text { exam. During teacher's correction of the students' exam paper, the teacher found that student's answers are weak and did not } \\
\text { meet the criteria required for success and thus would not qualify the student to enter the university. The fifth dilemma is followed } \\
\text { by two questions. }\end{array}$ \\
\hline
\end{tabular}

Each of the five dilemmas is followed by several questions related to different aspects of the situation. The respondent is asked to answer these questions in a selective manner (multiple choice) by selecting one of the six available options (A, B, C, D, E, and F) which is most in agreement with his/her thinking and clarifying the justifications of the choice; that is, what supports the issued moral judgment.

\subsubsection{Moral Judgment Scale Validity}

Validity of the developed Moral Judgement Scale was confirmed by presenting it to (10) specialized and experienced arbitrators to express their views on whether the scale is appropriate for the purpose of this study by reviewing its content, clarity of the paragraphs, the language, suitability of the scale for measuring individual moral judgement response, scale correction, and time required for scale application.

All of the scale dilemmas were agreed upon by all arbitrators (100\%). Some arbitrators expressed their views on few wordings changes. The researchers made the amendments in light of the recommendations and views agreed upon by $80 \%$ or more arbitrators. This made the scale in its final version.

\subsubsection{Moral Judgment Scale Reliability}

Reliability of the developed Moral Judgement Scale was confirmed by applying the test and re-test method to (38) students selected randomly from outside the study population and then re-applying the test to the same students after two weeks. The Pearson correlation coefficient was calculated between the two probes (see Table 3).

Table 3. Moral judgement scale reliability calculations

\begin{tabular}{|c|c|c|c|}
\hline & Arithmetic Mean & Standard Deviation & Pearson Correlation Coefficient Factor \\
\hline First Probe & 76.71 & 6.92 & \multirow{2}{*}{$86.3^{*}$} \\
\hline Second Probe & 76.81 & 6.73 & \\
\hline
\end{tabular}

* Statistically significant at the level of $(\alpha=0.01)$

The researchers considered the value of correlation coefficient of (86.3) sufficient for the purpose of conducting this study. The researchers also confirmed using this method the clarity of instructions for applying the scale individually, clearness of the dilemmas and the following questions, precision of the language, and fitting of the time allocated to complete the scale.

\subsubsection{Moral Judgment Scale Scoring}

The five dilemmas of the developed Moral Judgment Scale are followed by a number of questions. Each question has six (6) answers options (A, B, C, D, E, and F), and each answer is given a specific score ranging from (1) to (6). Taking into account that the answers (from A to E) are not arranged in order in each dilemma. The score of each answer represents a specific moral judgment stage of Kohlberg (see Table 4). 
Table 4. Moral judgment scale-answers scoring

\begin{tabular}{cl}
\hline Answer Score & Moral Judgment Stage \\
\hline 1 & Stage One: Rewards and Punishment \\
2 & Stage Two: Simple Reciprocity \\
3 & Stage Three: Social Approval/Personal Relationships \\
4 & Stage Four: Upholding/enforcing norms and Laws \\
5 & Stage Five: Broad Social Contract Issues \\
6 & Stage Six: Universal Principles \\
\hline
\end{tabular}

The moral judgment of the respondent is estimated by the total scale score which ranges from (20) as the minimum score up to (120), the highest score. Scale score rubrics for the moral judgment levels and moral judgment stages are presented in Table 5 and Table 6 respectively.

Table 5. Scale scoring rubrics of moral judgment level

\begin{tabular}{ll}
\hline Total Score & Moral Judgment Level \\
\hline $20-40$ & Level One: Pre-Conventional Morality \\
$41-80$ & Level Two: Conventional Morality \\
$81-120$ & Level Three : Post-Conventional Morality \\
\hline
\end{tabular}

Table 6. Scale scoring rubrics of moral judgement stage

\begin{tabular}{ll}
\hline Total Score & Moral Judgment Stage \\
\hline 20 & Stage One: Rewards and Punishment \\
$21-40$ & Stage Two: Simple Reciprocity \\
$41-60$ & Stage Three: Social Approval/Personal Relationships \\
$61-80$ & Stage Four: Upholding/enforcing norms and Laws \\
$81-100$ & Stage Five: Broad Social Contract Issues \\
$101-120$ & Stage Six: Universal Principles \\
\hline
\end{tabular}

\subsubsection{Applying the Moral Judgement Scale}

The developed Moral Judgement Scale was distributed to the study participants (345 students) in the second semester of the academic year 2018/2019 at the School of Educational Sciences at the University of Jordan. Students were asked to complete the scale during weekly program meetings and during the students' lectures, after obtaining the necessary approvals. The researchers retrieved all the scale documents after the distribution.

The breakdown of students who completed successfully the Moral Judgment Scale according to the study variables are presented in Table 7.

Table 7. Breakdown of study participants according to the study variables

\begin{tabular}{|c|c|c|c|c|c|c|}
\hline \multirow{3}{*}{ Program } & \multirow{2}{*}{\multicolumn{2}{|c|}{ Students }} & \multicolumn{4}{|c|}{ Academic Achievement } \\
\hline & & & \multicolumn{2}{|c|}{ Low } & \multicolumn{2}{|c|}{ High } \\
\hline & $\mathrm{f}$ & $\%$ & $\mathrm{f}$ & $\%$ & $\mathrm{f}$ & $\%$ \\
\hline Classroom teacher & 115 & $33.33 \%$ & 51 & $31.48 \%$ & 64 & $34.97 \%$ \\
\hline Counseling and Mental health & 77 & $22.32 \%$ & 35 & $21.60 \%$ & 42 & $22.95 \%$ \\
\hline Early Childhood Education & 35 & $10.14 \%$ & 20 & $12.35 \%$ & 15 & $8.20 \%$ \\
\hline Library and Information Science & 31 & $8.99 \%$ & 18 & $11.11 \%$ & 13 & $7.10 \%$ \\
\hline Special Education & 87 & $25.22 \%$ & 38 & $23.46 \%$ & 49 & $26.78 \%$ \\
\hline Total & 345 & $100 \%$ & 162 & $100 \%$ & 183 & $100 \%$ \\
\hline
\end{tabular}

f: frequency; \%: percentage.

Table 7 shows that that (33.33\%) of study participants are from the "Classroom Teacher" program, followed by (25.22\%) from the "Special Education" program. The lowest contribution was from the "Early Childhood Education" program with (10.14\%). It is also found that (162) students are "Low Academic Achievement" 
students, and (183) students are "High Academic Achievement". This indicates that "High Academic Achievement" students are dominant among the study participants.

\subsubsection{Confidentiality}

All study participants were informed of the study research terms, its purpose, tools, and data analysis before participating in the study. The researchers confirmed to all participants the confidentiality and the right to withdraw from the study at any time, and to withdraw any information they have provided without being subjected to deprivation in any form.

\subsection{Statistical Analysis}

Frequency and percentage of students' responses on the Moral Judgment Scale were used to analyze both moral judgment level and moral judgment stage of Kohlberg. Mann-Whitney test was used to compare mean ranks of the moral judgment levels of education profession ethics according to the academic achievement variable. The Kruskal-wallis test was used to determine differences in moral judgement stages of education profession ethics according to the students' program variable.

\section{Results}

In this section, results are discussed in the order of the research questions outlined in section (1.4).

3.1 Results of the Prevailing Moral Judgment Level Among the Students of the School of Educational Sciences at the University of Jordan

The frequency and percentage of students' responses on the Moral Judgement Scale were calculated as presented in Table 8.

Table 8. Students' responses-moral judgment level $(n=345)$

\begin{tabular}{lcc}
\hline & \multicolumn{2}{c}{ Students } \\
\hline Moral Judgment Level & $\mathrm{f}$ & $\%$ \\
First Level : Pre-Conventional Morality & 0 & $0.0 \%$ \\
Second Level : Conventional Morality & 308 & $89.3 \%$ \\
Third Level : Post-Conventional Morality & 37 & $10.7 \%$ \\
\hline
\end{tabular}

Table 8 shows that the prevailing moral judgment level among the students of the School of Educational Sciences at the University of Jordan is the second level, the "Conventional Morality" level of Kohlberg with (308) students for $(89.3 \%)$. While, (37) students with $(10.7 \%)$ were found at the third level, the "Post-Conventional Morality" level of Kohlberg. However, no students appeared in the first level, the "Pre-Conventional Morality" level of Kohlberg.

3.2 Results of the Prevailing Moral Judgment Stage Among the Students of the School of Educational Sciences at the University of Jordan

The frequency and percentage of students' responses on the Moral Judgement Scale were calculated as presented in Table 9.

Table 9. Students' responses-moral judgment stage $(n=345)$

\begin{tabular}{lcc}
\hline & \multicolumn{2}{c}{ Students } \\
\hline Moral Judgment Stage & $\mathrm{f}$ & $\%$ \\
Stage One: Rewards and Punishment & 0 & $0 \%$ \\
Stage Two: Simple Reciprocity & 0 & $0 \%$ \\
Stage Three: Social Approval/Personal Relationships & 62 & $18 \%$ \\
Stage Four: Upholding/enforcing norms and laws & 245 & $71 \%$ \\
Stage Five: Broad Social Contract Issues & 38 & $11 \%$ \\
Stage Six: Universal Principles & 0 & $0 \%$ \\
\hline
\end{tabular}

f: frequency; \%: percentage.

Table 9 shows that the prevailing moral judgment stage among students of the School of Educational Sciences at the University of Jordan is the fourth stage of Kohlberg moral judgment, the "Upholding/enforcing norms and 
laws" stage, with (245) students contributing to (71\%) of the total students. The third stage of Kohlberg, the "Social Approval/Personal Relationships" came at the second rank with (62) students contributing to $18 \%$ of the total students. While, the fifth stage of Kohlberg, the "Broad Contract Issues" came at the third rank with (38) students contributing to (11\%) of the total students. However, no students appeared in "stage one", "stage two", nor in "stage six" of Kohlberg moral judgement.

3.3 Results If There Are Statistically Significant Differences $(A=0.05)$ Between the Arithmetical Averages of Moral Judgment Levels of Education Profession Ethics Due to the Academic Achievement and Program of the Students at the School of Educational Sciences at the University of Jordan?

To answer this question, the Mann-Whitney test was used to compare mean ranks of the moral judgment levels of education profession ethics according to the academic achievement variable. The Kruskal-wallis test was used to determine differences according to the program variable.

\subsubsection{Results According to the Academic Achievement Variable}

The Mann-Whitney test was used to compare mean ranks of the moral judgment levels of education profession ethics according to the academic achievement variable (see Table 10).

Table 10. Moral judgment levels differences according to students' academic achievement

\begin{tabular}{ccccccc}
\hline $\begin{array}{c}\text { Academic } \\
\text { Achievement }\end{array}$ & Number & $\begin{array}{c}\text { Mean } \\
\text { Rank }\end{array}$ & $\begin{array}{c}\text { Sum } \\
\text { of Ranks }\end{array}$ & U value & Z value & $\begin{array}{c}\text { Level of } \\
\text { significance }\end{array}$ \\
\hline Low & 162 & 154.50 & 25029 & 11826 & -6.048 & $.000^{*}$ \\
High & 183 & 189.38 & 34656 & & \\
\hline
\end{tabular}

* Statistically significant at the level of $(\alpha=0.05)$.

Table 10 shows statistically significant differences at $(\alpha=0.05)$ in the moral judgment levels between the "low academic achievement" and the "high academic achievement" students. The mean rank for the "high academic achievement" students was (189.38) while the mean rank for the "low academic achievement" students was (154.50). Accordingly, differences in the moral judgment levels of education profession ethics were in favor of "high academic achievement" students.

\subsubsection{Results According to the Program Variable}

The Kruskal-wallis test was used to compare mean ranks of the moral judgment levels of ethics in education profession according to the program variable (see Table 11).

Table 11. Moral judgment levels differences according to students' program

\begin{tabular}{|c|c|c|c|c|}
\hline Program & Number & $\begin{array}{l}\text { Mean } \\
\text { Rank }\end{array}$ & Chi-squared test & $\begin{array}{c}\text { Level of } \\
\text { significance }\end{array}$ \\
\hline Library and Information Science & 31 & 160.06 & & \\
\hline Early Childhood Education. & 35 & 169.29 & & \\
\hline Counseling and Mental health & 77 & 179.14 & 3.065 & $.547^{*}$ \\
\hline Special Education & 87 & 174.33 & & \\
\hline Classroom teacher & 115 & 172.50 & & \\
\hline
\end{tabular}

* Statistical significance at the level of statistical significance $(\alpha=0.05)$.

Table 11 shows no statistically significant differences at $(\alpha=0.05)$ in the moral judgment levels attributable to the students' program.

3.4 Results If There Are Statistically Significant Differences $(A=0.05)$ Between the Arithmetical Averages of Moral Judgment Stages of Education Profession Ethics Due to the Academic Achievement and Student Program at the School of Educational Sciences at the University Of Jordan

To answer this question, the Mann-Whitney test was used to compare the mean ranks of the moral judgment stages of education profession ethics according to the academic achievement variable, and the Kruskal-wallis test was used to determine differences according to the program variable. 


\subsubsection{Academic Achievement Variable}

The Mann-Whitney test was used to compare the mean ranks of moral judgment stages of education profession ethics according to the academic achievement variable (see Table 12).

Table 12. Moral judgment stages differences according to students' academic achievement

\begin{tabular}{ccccccc}
\hline $\begin{array}{c}\text { Academic } \\
\text { Achievement }\end{array}$ & Number & $\begin{array}{c}\text { Mean } \\
\text { Rank }\end{array}$ & $\begin{array}{c}\text { Sum of } \\
\text { Ranks }\end{array}$ & U value & Z value & $\begin{array}{c}\text { Level of } \\
\text { significance }\end{array}$ \\
\hline Low & 162 & 126.25 & 20453 & 7250 & -10.281 & $.000 *$ \\
High & 183 & 214.38 & 39232 & & \\
\hline
\end{tabular}

* Statistical significance at the level of statistical significance $(\alpha=0.05)$

Table 12 shows statistically significant differences at $(\alpha=0.05)$ in moral judgment stages between the "low academic achievement" and the "high academic achievement" students. The mean rank for the "high academic achievement" stage was (214.38) while the mean rank for the "low academic" achievement stage was (126.25). Accordingly, differences in moral judgment stages of education profession ethics were in favor of the "high academic achievement" students.

\subsubsection{Program Variable}

The Kruskal-wallis test was used to compare the mean ranks of moral judgment stages of education profession ethics according to the program variable (see Table 13).

Table 13. Moral judgment stages differences according to students' program

\begin{tabular}{lcccc}
\hline Program & Number & $\begin{array}{c}\text { Mean } \\
\text { Rank }\end{array}$ & Chi-squared test & $\begin{array}{c}\text { Level of } \\
\text { significance }\end{array}$ \\
\hline Library and Information Science & 31 & 145.00 & & \\
Early Childhood Education. & 35 & 166.43 & & $.004^{*}$ \\
Counseling and Mental health & 77 & 181.14 & 15.378 & \\
Special Education & 87 & 195.97 & & \\
Classroom teacher & 115 & 159.72 & & \\
\hline
\end{tabular}

* Statistical significance at the level of statistical significance $(\alpha=0.05)$.

Table 13 shows there are statistically significant differences at $(\alpha=0.05)$ in moral judgment stages attributable to the students' program.

To find out the source of the differences among students' programs, the Mann-Whitney U test was performed and results are presented in Table 14. 
Table 14. Comparison of moral judgment stages according to students' program

\begin{tabular}{|c|c|c|c|c|c|c|}
\hline $\begin{array}{c}\text { Comparis } \\
\text { on }\end{array}$ & Program & Number & $\begin{array}{l}\text { Mean } \\
\text { Rank }\end{array}$ & $\begin{array}{l}\text { Sum of } \\
\text { Ranks }\end{array}$ & Value U & $\begin{array}{c}\text { Level of } \\
\text { significance }\end{array}$ \\
\hline \multirow{2}{*}{1} & Library and Information Science & 31 & 31.31 & 970.5 & 474.5 & \multirow[b]{2}{*}{.277} \\
\hline & Early Childhood Education. & 35 & 35.44 & 1240.5 & & \\
\hline \multirow{2}{*}{2} & Library and Information Science & 31 & 46.60 & 1444.5 & 948.5 & \multirow{2}{*}{$.044 *$} \\
\hline & Counseling and Mental health & 77 & 57.68 & 4441.5 & & \\
\hline \multirow{2}{*}{3} & Library and Information Science & 31 & 46.18 & 1431.5 & 935.5 & \multirow{2}{*}{$.000 *$} \\
\hline & Special Education & 87 & 64.25 & 5589.5 & & \\
\hline \multirow{2}{*}{4} & Library and Information Science & 31 & 68.92 & 2136.5 & 1640.5 & \multirow{2}{*}{.421} \\
\hline & Classroom teacher & 115 & 74.73 & 8594.5 & & \\
\hline \multirow{2}{*}{5} & Early Childhood Education & 35 & 53.24 & 1863.5 & 1233.5 & \multirow{2}{*}{.381} \\
\hline & Counseling and Mental health & 77 & 57.98 & 4464.5 & & \\
\hline \multirow{2}{*}{6} & Early Childhood Education. & 35 & 53.90 & 1886.5 & 1256.5 & \multirow{2}{*}{$.027 *$} \\
\hline & Special Education & 87 & 64.56 & 5616.5 & & \\
\hline \multirow{2}{*}{7} & Early Childhood Education. & 35 & 77.84 & 2724.5 & 1930.5 & \multirow{2}{*}{.664} \\
\hline & Classroom teacher & 115 & 74.79 & 8600.5 & & \\
\hline \multirow{2}{*}{8} & Counseling and Mental health & 77 & 79.05 & 6086.5 & 3083.5 & \multirow{2}{*}{.234} \\
\hline & Special Education & 87 & 85.56 & 7443.5 & & \\
\hline \multirow{2}{*}{9} & Counseling and Mental health & 77 & 103.43 & 7964 & 3894 & \multirow{2}{*}{.094} \\
\hline & Classroom teacher & 115 & 91.86 & 10564 & & \\
\hline \multirow{2}{*}{10} & Special Education & 87 & 113.61 & 9884 & 3949 & \multirow{2}{*}{$.001 *$} \\
\hline & Classroom teacher & 115 & 92.34 & 10619 & & \\
\hline
\end{tabular}

* Statistically significant at the level of $(\alpha=0.05)$.

Results in Table 14 show the following:

1) There were no statistically significant differences at $(\alpha=0.05)$ in the moral judgment stage between "Library and Information Science" and "Early Childhood Education" programs based on the value of U (474.5), with a level of significance of (0.277).

2) There were no significant differences at $(\alpha=0.05)$ in the moral judgment stage between "Library and Information Science" and "classroom teacher" programs based on the value of U (1640.5), with a level of significance (0.21).

3) There were statistically significant differences at $(\alpha=0.05)$ in the moral judgment stage between "Library and Information Science" and "Counseling and Mental health" programs, based on the value of U (948.5) at a significant level (0.044), while the mean rank for the "Counseling and Mental health" program was (57.68). This confirms that the differences in the moral judgment stage of education profession ethics were in favor of the "Counseling and Mental health" program.

4) There were significant differences at $(\alpha=0.05)$ in the moral judgment stage between "Library and Information Science" and "Special education" programs, based on the value of U (935.5) with a level of significance (.000), and the mean rank for "Library and Information Science" program was (46.18), while the mean rank for "Special education" was (64.25). Accordingly, differences in the moral judgment stage of education profession ethics were in favor of the "special education" program.

5) There were no statistically significant differences at $(\alpha=0.05)$ in the stage of moral judgment between "Early Childhood Education" and "Counseling and Mental health" programs based on the value of U (1233.5) with a level of significance (0.381).

6) There were statistically significant differences at $(\alpha=0.05)$ in the stage of moral judgment between "Early Childhood Education" and "Special Education" programs, based on the value of U (1256.5) at a mean level (0.277), while the mean rank for "Special Education" program was (64.56). This endorses that differences in the moral judgment stage of education profession ethics were in favor of "Special Education" program.

7) There were no significant differences at $(\alpha=0.05)$ in the moral judgment stage between "Early Childhood Education" and "Classroom teacher" programs based on the value of U (1930.5) with a level of significance of (0.664). 
8) There were no statistically significant differences at $(\alpha=0.05)$ in the moral judgment stage between "Counseling and Mental health" and "Special Education" programs based on the value of U (3083.5) with a level of significance (0.234).

9) There were no significant differences at $(\alpha=0.05)$ in the moral judgment stage between "Counseling and Mental health" and "Classroom teacher" programs based on the value of U (3894) with a level of significance of (0.094).

10- There were statistically significant differences at $(\alpha=0.05)$ in the moral judgment stage between "Special Education" and "Classroom teacher" programs, based on the value of U (3949) with a level of significance of (.001), while the mean rank for "Classroom teacher" program was (92.34). This verifies that the differences in the moral judgment stage of education profession ethics were in favor of the "Special Education".

\section{Discussion}

This study provides a brief overview of the current situation of moral judgment measurements for the education profession ethics among pre-service teachers at the School of Educational Sciences at the University of Jordan. The findings of the study demonstrate that most students (89.3\%) are at the conventional morality level of Kohlberg moral judgement. This is in accordance with the published studies (King \& Mayhew, 2002; Migdady, 2015). Pre-service teachers at the conventional morality level are able to motivate students' learning and development by increasing their own awareness of moral and ethical responsibilities. However, only limited percentage of students (10.7\%) were at the post-conventional morality level. According to Kohlberg (1984), access to post-conventional morality means moral autonomy. Individuals reaching the highest levels of morality are able to implement critical thinking on present rules. They will arrive at the right conclusions even in difficult situations when they are under pressure from others. Hence if preservice teachers programs could foreground the contribution of moral judgement, then higher percentage of pre-service teachers will reach the post-conventional morality level and thus can have a better understanding of moral judgement and are capable of influencing their students with regard to ethics and morals.

On the other hand, study results indicated that Kohlberg fourth stage (Upholding/enforcing norms and Laws) is dominant among pre-service teachers at the School of Educational Sciences at the University of Jordan. Again, these results are consistent with the published results (Maqaldeh \& Bani-Mustafa, 2014; Khatib, 1988). During Kohlberg fourth stage, individuals gradually became interested in society as a whole and also show importance of maintaining the social order (Lapsley, 1996). Results also showed students in the third moral judgement stage of Kohlberg (social approval/personal relationships) with (18\%) and in the fifth stage (Reasoning on Broad Social Contract Issues) with (11\%). According to Kohlberg (1984), third-stage individuals are in pre-conventional morality level, same as stage four, but generally in stage three, individuals tend to believe that good behaviors mean good motivation and belief that personal feelings such as trust and interest make others behave well and morally (Colby \& Kohlberg, 1987). While individuals in stage five are at post-conventional morality level who are beginning to realize that a society that is working smoothly in the fourth stage is not necessarily a good social system. This variation in students' distribution in moral judgement stages can be explained that all students at the School of Educational Sciences at the University of Jordan are enrolled in their fourth academic year, the second semester, in field training practice. During this training, students are distributed to co-operative schools according to their program specialization. Accordingly, students start to deal with the community and get acquainted with the laws and norms of the education profession. Since data collection for this research study was during the second semester of the academic year; the duration which students are distributed to co-operative schools. Hence, some students might have interacted differently with the community which was indicated by showing some students in the third moral judgement stage and others in the fifth moral judgment stage of Kohlberg. Although, the autocratic society might be well structured, organized and controlled, it will be hardly considered morally ideal. People start asking questions, what makes the community good? Many may argue that they do not generally support breaking the law, because laws are considered social contracts in which individuals come to an understanding to uphold so that we can change them through democratic processes, but the society moral rights must be protected.

According to Kohlberg (1984), moral development proceeds in the same manner as cognitive development. This is in consistent with study results in which there were significant differences in the moral judgment levels and in the moral judgment stages between the "low academic achievement" and the "high academic achievement" students. Differences in the moral judgement levels and stages of education profession ethics were in favor of the "high academic achievement" students.

Moreover, results showed no significant differences in the moral judgment levels attributable to the students' program. Most students from all the programs were found at the conventional morality level, in which their sense 
of morality is tangled to the personal and societal relationships. At this level, pre-service teachers believe it is necessary to maintain positive relationships and societal order so they continue to accept the rules of authority figures. This might be elucidated that all programs at the University of Jordan has to a certain extent limited focus on the moral development of its students. The student outcome from all the programs yielded the same output of moral judgement level; the expanded scale of moral judgement as described by the researchers.

On the other hand, study results showed significant differences in the moral judgment stages according to the students' program. The programs that showed statistically significant differences in the moral judgment stages are: (1) "Library and Information Science" and "Counseling and Mental health"; (2) "Library and Information Science" and "Special education"; (3) "Early Childhood Education" and "Special Education"; (4) "Special Education" and "Classroom teacher". It can be said that when comparing moral judgement at a narrower scale moral judgement stage - differences between the programs had been observed. This might be due to the fact that the five examined programs have different objectives of educational activities or learning-cognitive (knowledge), psychomotor (skills), and affective (attitude, ethics, or self). Accordingly, students developed different moral judgment stages in these programs.

\section{Conclusion}

The moral judgment prevailing among students of the School of Educational Sciences at the University of Jordan is the conventional morality level and the fourth stage (upholding/enforcing norms and laws) of Kohlberg. These findings argue that investment in pre-service teachers education is required to increase teachers' moral judgment so they can embody ethical principles and demonstrate ethical behavior in their professional behavior while practicing the education profession. More attention should be made to the "low academic achievement" students.

\section{Recommendations}

We call for the inclusion of moral education in pre-service teachers' education curricula to improve skills, knowledge and awareness of future teachers. More investment is recommended in pre-service teachers' education programs by focusing on perfection and spirituality rather than adding more materials to university curricula. By this, long-term benefits for teachers and learners moral judgement will be maintained.

\section{References}

Abdul Fattah, F. (2001). The Ethical Thinking Scale for Adults-Instruction Manual. Cairo: The Anglo Library.

Al-Hjrieh, A. (2009). The Importance of the Charter of Education Ethics and its Objectives. Journal of Educational Development, 51, 39-47.

Al-Raqqad, H., \& Al-Khawaldeh, I. A. (2016). The Levels of Moral Thinking and its Relation to Decision Making among Jordanian University Students. Journal of the Faculty of Education for Educational and Human Sciences, 25, 18-41.

Al-Sawalma, J. (2014). The policies of teacher training and recruitment, "The Jordanian Case", the Arab Organization for Education, Culture and Science. Tunisia and the Queen Rania Academy for Teacher Training, Jordan.

Berkowitz, M., \& Bier, M. (2004). Research-based character education. The Annals of the American Academy of Political and Social Science, 591, 72-85. https://doi.org/10.1177/0002716203260082

Colby, A., \& Kohlberg, L. (1987). The measurement of moral judgment (Vol. 1). Cambridge University Press: New York.

Colby, A., Kohlberg, L., Speicher, B., Hewer, A., Candee, D., \& Gibbs, J. (1987). The measurement of moral judgment (Vol. 1 and 2), Cambridge University Press: New York.

Cummings, R., Dyas, L., Maddux, C. D., \& Kochman, A. (2001). Principled moral reasoning and behavior of preservice teacher education students. American Education Research Journal, 38(1), 143-158. https://doi.org/10.3102/00028312038001143

Goodlad, J. I., Soder, R., \& Sirotnik, K. A. (Eds) (1990). The moral dimension of teaching. Jossey-Bass: San Francisco, CA,

Honig, P., \& Lalonde, R. (2014). To what extent should physical education become a vehicle for moral development? Journal of Physical Education, Recreation \& Dance, 85(4), 46-49. https://doi.org/10.1080/07303084.2014.884841

Jordan Ministry of Education. (2018). Code of Conduct and Professional Ethics for Teachers, National Charter of the Education Profession, Department of Supervision and Educational Training, Section I: Code of 
Conduct.

Khatib, B. (1988). Distribution of Students of the University of Jordan at the Stages of Moral Growth by their Social and Cultural Platform (Unpublished master thesis). Department of Psychology, Faculty of Education, University of Jordan.

Killen, M., \& Smetana, J. (2006). Handbook of Moral Development. Lawrence Erlbaum Associates Publishers, USA. https://doi.org/10.4324/9781410615336

Kohlberg, L. (1984). The Psychology of Moral Development: The nature and validity of moral stages. Harper and Row, New York, USA.

Lapsley, D. (1996). Moral Psychology. Westview Press, Boulder, CO.

Maqaldeh, T., \& Bani-Mustafa, M. (2014). Ethical thinking and its relationship to the level of optimism and pessimism among the students of Yarmouk University (Unpublished master thesis). Yarmouk University, Faculty of Education.

Maxwell, B. (2017). Codes of Professional Conduct and Ethics Education for Future Teachers. Philosophical Inquiry in Education, 24(4), 323-347.

Maxwell, B., Tremblay-Laprise, A., Filion, M., Boon, H., Daly, C., ... Walters, S. (2016). A Five-Country Survey on Ethics Education in Pre Service Teaching Programs. Journal of Teacher Education, 67(2), 135-151. https://doi.org/10.1177/0022487115624490

Migdady, Y. (2015). Moral Reasoning Development and its Relationship to Eudemonic Well-Being and Positive Social Behavior. Jordanian Journal of Educational Sciences, 11(3), 269-284.

Nucci, L., Drill, K., Larson, C., \& Browne, C. (2005). Preparing pre-service teachers for character education in urban elementary schools: The UIC initiative. Journal of Research in Character Formation, 3(2), 81-96.

Rest, J. (1979). Development in judging moral issues. University of Minnesota Press: Minneapolis, MN.

Trups-Kalne, I. (2018). Psychological Aspects of Moral Development: History and Recent Studies. Proceedings of the International Scientific Conference (Volume VII, May 25th-26th, pp. 280-290). https://doi.org/10.17770/sie2018vol1.3400

Warnick, B., \& Silverman, S. (2011). A Framework for Professional Ethics Courses in Teacher Education. Journal of Teacher Education, 62(3), 273-285. https://doi.org/10.1177/0022487110398002

Weissbourd, R. (2003). Moral Teachers, Moral Students. Educational Leadership, 60(6), 6-11.

Winston, M. (2007). Ethical Leadership and Ethical Decision Making: A Meta-Analysis of Research Related to Ethics Education. Library \& Information Science Research, 29(2), 230-251. https://doi.org/10.1016/j.lisr.2007.04.002

\section{Copyrights}

Copyright for this article is retained by the author(s), with first publication rights granted to the journal.

This is an open-access article distributed under the terms and conditions of the Creative Commons Attribution license (http://creativecommons.org/licenses/by/4.0/). 